\title{
Transferring ART research into education in Brazil
}

Maria Fidela de Lima NAVARRO' ${ }^{1}$, Karin Cristina da Silva MODENA², Maria Cristina Carvalho de Almendra FREITAS ${ }^{3}$, Ticiane Cestari FAGUNDES ${ }^{4}$

\begin{abstract}
1- DDS, PhD, Professor, Department of Dental Materials, Endodontics and Operative Dentistry, Bauru School of Dentistry, University of São Paulo, Bauru, SP, Brazil.

2- DDS, PhD Student, Department of Operative Dentistry, Endodontics and Dental Materials, University of São Paulo, Bauru School of Dentistry, Bauru/SP, Brazil. 3- DDS, MSc Student, Department of Operative Dentistry, Endodontics and Dental Materials, University of São Paulo, Bauru School of Dentistry, Bauru/SP, Brazil. 4- DDS, MSc, PhD, Fellow, Department of Operative Dentistry, Endodontics and Dental Materials, University of São Paulo, Bauru School of Dentistry, Bauru/ SP, Brazil.
\end{abstract}

Corresponding address: Maria Fidela de Lima Navarro - Disciplina de Dentística - Alameda Dr. Octávio Pinheiro Brisolla, 9-75 - $17012-901$ - Cidade Universitária, Bauru/SP - Brazil - Phone: + 5514 3235-8214 - Fax: + 5514 3224-1388 - e-mail: mflnavar@usp.br

\section{ABSTRACT}

\begin{abstract}
The aim of this study was to evaluate the teaching of the Atraumatic Restorative Treatment (ART) approach in Brazilian dental schools. Materials and Methods: A questionnaire on this subject was sent to Pediatric Dentistry, Operative Dentistry and Public Health Dentistry professors. The questions approached the followig subjects: the method used to teach ART, the time spent on its teaching, under which discipline it is taught, for how many years ART has been taught and its effect on the DMFT index. Results: A total of 70 out of 202 dental schools returned the questionnaire. The ART approach is taught in the majority of the Brazilian dental schools (96.3\%), and in most of these schools it is taught both in theory and in clinical practice $(62.9 \%)$. The majority $(35.3 \%)$ of professors teach ART for 8 hours, and most often as part of the Pediatric Dentistry discipline (67.6\%). It has been taught for the last 7 to 10 years in $34.3 \%$ of dental schools. Most professors did not observe a change in the DMFT index with this approach. There is a diversity in the teaching of ART in Brazil in terms of the number of hours spent, the teaching method (theory and practice), and the disciplines involved in its teaching. Conclusions: It is necessary to address the training of professors in the ART approach for the whole country. An educational model is proposed whereby a standard ART module features as part of other preventive and restorative caries care educational modules. This will facilitate and standardize the introduction and adoption of the ART approach in undergraduate education in Brazil.
\end{abstract}

Key words: Dental caries. Atraumatic Restorative Treatment (ART). Dental restoration. Dental education. Oral health. Attitude.

\section{INTRODUCTION}

Atraumatic Restorative Treatment (ART) takes a special place within the group of minimal intervention approaches for the management of dental caries ${ }^{4,16}$. This treatment approach was recognized and endorsed by the World Health Organization (WHO) for bringing restorative dental treatment to people who would not normally have access to dental care. The ART approach has become available through the combination of a better understanding of the dental caries process, permitting minimal cavity preparations and effective use of adhesive restorative materials ${ }^{37}$. The procedure involves removal of carious tooth tissue using hand instruments only, followed by restoration usually with a glass-ionomer cement ${ }^{17,33,35}$.

Critics to the ART approach argue that in spite of the positive results in research carried out into the use of the ART approach in clinical trials ${ }^{9-11,14,16,20,36,38}$, many dental institutions in Brazil do not include this approach in their curricula. There is, however, no reliable information about the teaching of the ART approach in Brazil with respect to the theory, its laboratory and clinical teaching. 
Brazil is currently committed to the implementation of a Family Health Program (FHP) that aims to extend basic health care to the whole population. The FHP is changing from an emergency and restorative treatment model to one of disease prevention and health promotion for individuals as well as families and communities. This will make primary health care the foundation of the Brazilian healthcare system $^{21}$. The main characteristics of the FHP are: a focus on the family, use of a multidisciplinary team, preventive activities, assessment of population needs and intersectoral action to promote health care ${ }^{6,15}$. In addition to the FHP, the Brazilian Government has also started the Programa Brasil Sorridente (Brazil Smiling Program) that has the objective of improving oral health care for the Brazilian population. It is the first time that the Federal Government has developed a national oral health policy with a well established program and not solely based on oral health care. With this program, in addition to basic dental care, the population has access to specialized treatments, such as management of oral cancer, endodontics, orthodontics and surgery?

Thus, in Brazil, it is desirable to have, as soon as possible, dental practitioners who are competent theoretically and clinically in the ART approach, to enable them to implement the treatment required by the population under the responsability of each health team.
It was considered that a study regarding the teaching of ART in Brazil, covering all the regions of the country, would provide important information to health managers. This study might also enable the Brazilian authorities to find ways to facilitate the teaching and practice of ART in Brazilian dental institutions. Therefore, the aim of this study was to contact all dental schools in Brazil seeking information, through a questionnaire, from the professors from different disciplines regarding the teaching of ART at the undergraduate level, and to make recommendations based on the outcomes.

\section{MATERIAL AND METHODS}

\section{Questionnaire Development}

The authors prepared a short and straightforward questionnaire regarding the teaching of the ART approach, in such a way that professors could quickly and easily answer it. The questionnaire consisted of three sections: a) personal and institutional details; b) the method and the time used for teaching ART and the number of years the approach has been taught; and, c) the effects of ART on DMFT (Figure 1).

\section{Selection of the Study Population}

According to the Ministry of Education (MEC), at the time of sending the questionnaires there were 202 dental schools in Brazil. Twenty were in the North, 34 in the Northeast, 15 in the Center-

FIGURE 1- Questionnaire on teaching ART in dental institutions in Brazil

1. Professor:

2. Institution:

3. Address:

4. Is ART approach taught in your institution? Yes ( ) No ( )

5. If YES, how has it been taught?

Theoretically ( ) Laboratory practice ( ) Clinical practice ( )

5a. Time spent with ART teaching

Less than 8 hours ( ) 8 hours ( ) from 8 to 20 hours ( ) more than 20 hours ( )

$5 \mathrm{~b}$. As part of which discipline has ART been taught?

Pediatric Dentistry ( ) Public Health Dentistry ( ) Operative Dentistry ( )

Other ( ) Which one?

$5 \mathrm{c}$. For how long has the ART approach been taught?

6. With this approach, the DMFT has been the same ( ) worse ( ) 
west, 101 in the Southeast and 32 in the South of the country. The target population comprised all dental professors working in Pediatric Dentistry, Public Oral Health, or Operative Dentistry departments from private, regional and district dental institutions in Brazil.

\section{Procedure for Obtaining the Names and Addresses of Dental Professors}

The professors' e-mails were obtained from the websites of the universities and individual schools. When an institution did not have a website, or the names of professors were not readily available, the secretaries of the deans of these institutions were contacted by telephone to supply updated information about the professors' names and their electronic addresses. All addresses were entered into a computer database, using Microsoft Excel software.

\section{RESULTS}

A total of 70 of the 202 dental schools in Brazil answered the questionnaire, which represents an almost 35\% response rate. The question: "Is the ART approach taught in your institution?" was answered by the majority as "yes" (96.3\%); the remaining 3.7\% answered "no".

According to the respondents, ART is taught both in theory and in clinical practice in the majority of dental schools (62.9\%). In $14.3 \%$ of the dental schools, ART is taught through a combination of theoretical teaching, laboratory and clinical practice. ART is taught only through theoretical teaching in $13.3 \%$ of dental schools, only clinical teaching in $8.6 \%$, and only laboratory practice in $0.9 \%$ of schools (Figure 2 ).

Regarding the time spent with ART teaching, the majority of dental schools answered "8 hours" (35.3\%), followed by "from 8 to 20 hours" (29.5\%), "more than 20 hours" (27.6\%)," less than 8 hours" $(3.8 \%)$, while $3.8 \%$ did not answer (Figure 3).

Figure 4 summarizes the responses to the question "As part of which discipline has ART been taught?". The majority (67.6\%) stated that ART is taught in "Pediatric Dentistry", followed by "Public Health Dentistry" (45.7\%), "Operative

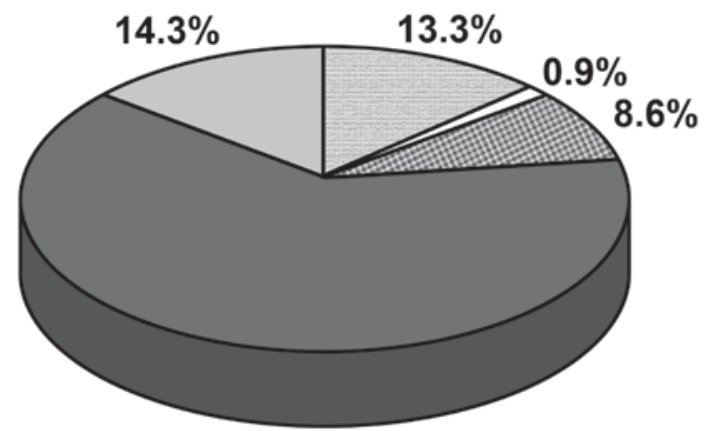

$62.9 \%$
Theoretically

\section{Laboratory practice}

Clinical practice

Theoretically + clinical practice

Theoretically + clinical practice + Laboratory practice

FIGURE 2- Answers given by professors from 70 dental schools in Brazil to the question "How is ART being taught?"

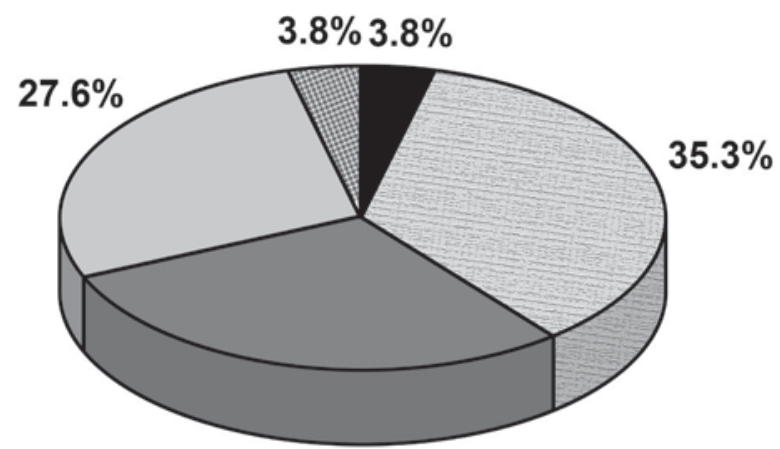

$29.5 \%$
Less than $8 \mathrm{~h}$

$8 \mathrm{~h}$

Between 8 and $20 \mathrm{~h}$

\section{More than $20 \mathrm{~h}$}

Did not answer

FIGURE 3- Percentage distribution of responses to the question "How much time is spent teaching ART"? 


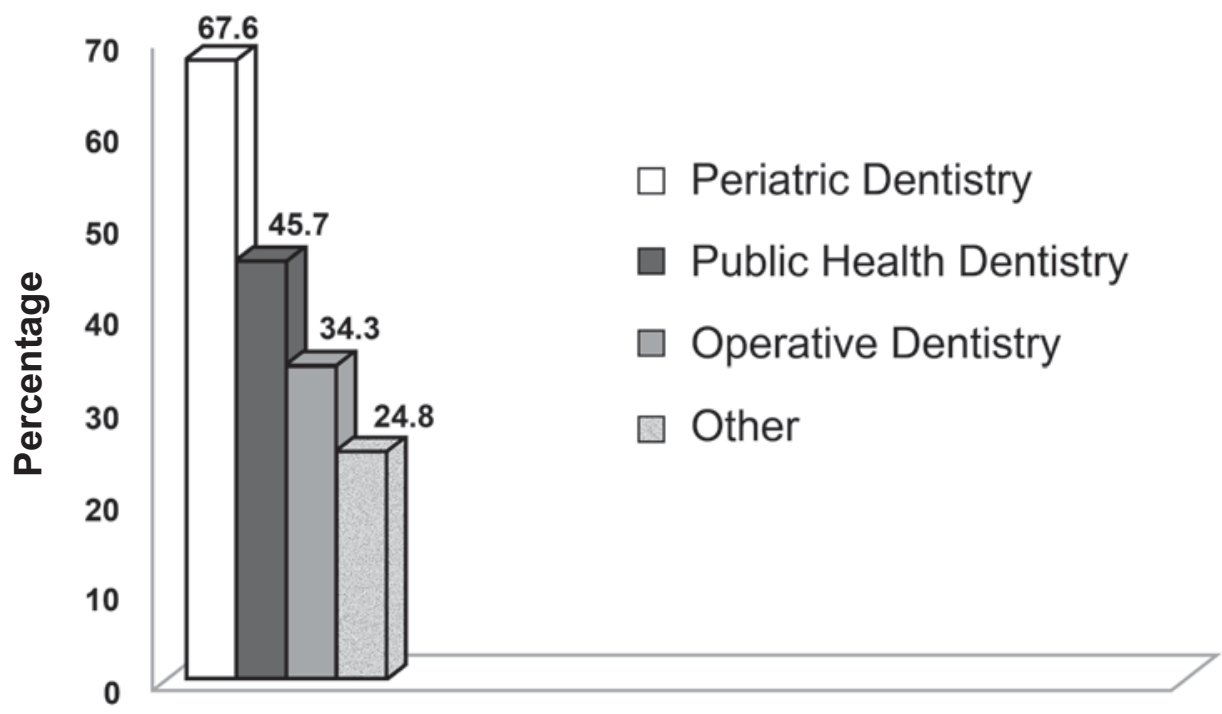

FIGURE 4- Distribution of the responses to the question "As part of which discipline has ART been taught?"
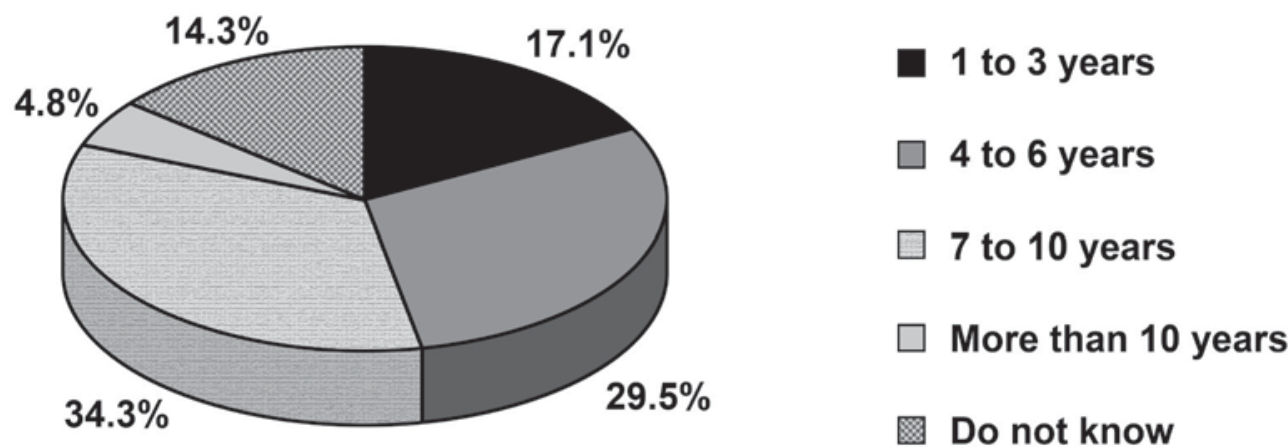

FIGURE 5- Percentage distribution of responses to the question "For how long has the ART approach been taught"?

Dentistry (34.3\%), and "Other disciplines" (24.8\%).

With respect to the question "For how long has the ART approach been taught?", the majority (34.3\%) answered that this approach has been taught for "7 to 10 years", while $29.5 \%$ answered "4 to 6 years", $17.1 \%$ answered " 1 to 3 years", $4.8 \%$ stated that ART has been taught for "more than 10 years" and $14.3 \%$ did not know (Figure $5)$.

As regards the DMFT index, none of the respondents stated that the DMFT was worse because of the ART approach. The majority $(66.7 \%)$ answered that the index had remained the same, and $33.3 \%$ did not know.

\section{DISCUSSION}

Since its introduction, the ART approach has become a well established caries management option (preventive and restorative), even though it might have some limitations under certain situations. ART is based on a preventive philosophy which includes early interception of the carious process by using different types of fluorides and, when necessary, minimally invasive intervention to conserve sound tooth tissue ${ }^{27}$. Thus, ART must not be used in isolation but should be included with preventive programs and health education to be effective by controlling the etiologic factors of caries. The educational activities and preventive procedures include diet counseling, oral hygiene instruction, plaque removal, and use of remineralizing agents ${ }^{40}$.

The ART approach has been incorporated in undergraduate curricula in a number of dental schools around the world. Examples are, Thamarasset Dental School in Thailand and Muhimbili Dental School in Tanzania ${ }^{23,24}$. The approach is taught in dental schools with the aim 
of promoting public health to those who do not normally have access to oral health treatment ${ }^{12}$.

In this context, many countries have shown dissatisfaction regarding the insignificant contribution of preventive and restorative care to the oral health of their population. Approximately two-thirds of the world population do not have any professional oral care ${ }^{32}$. For example, twenty seven million Brazilians, almost $15 \%$ of the total population, have never received any dental treatment, according to a demographic survey performed in $1998^{22}$. Since then the number of Brazilians who have access to oral health programs of prevention and treatment of oral diseases has increased. For this sector of the population, the Family Health Program (FHP) and the "Brazil Smiling Program" that the Brazilian federal government has established, will take trained medical and dental practitioners to rural and suburban areas where the population does not have access to health treatment. The ART approach was originally developed for this sector of the population so it is necessary to know if dental schools are teaching this approach to their students.

There are many studies that have used questionnaires to evaluate the curricular structure, teaching philosophies, knowledge, the skills of teaching, the status and factors associated with organizational innovation in dental schools ${ }^{1,25,29}$. In the present study, data was collected from nearly $35 \%$ of all dental schools in Brazil, which represents 70 schools. Although in our study we used a short questionnaire, with the intention of improving the response rate, other similar studies have had a response rate ranging from $70.5 \%$ to $100 \%{ }^{1,25,29}$. This difference in response rates may have occurred because Brazilian people are resistant to answering questionnaires for evaluation; for example, some studies have responses as low as $8.4 \%{ }^{34}, 35 \%{ }^{13}$ and $39.5 \%^{3}$. Another possible reason is that some of the non-respondent dental schools might not as yet have incorporated ART within their curricula and were reluctant to report on this.

The high percentage $(96.3 \%)$ of the responding dental schools that teach ART to their students reveal the importance that their professors attach to ART. The majority of the professors (62.9\%) teach the ART approach only theoretically and clinically, however laboratory practice is important to teach some of the finer details that the approach requires ${ }^{27}$, such as proper cavity cleaning (preparation) and glass ionomer cement manipulation.

Most dental schools claim that they spend between 8 and 20 hours on the teaching of ART. We believe that a minimum of 8 hours for theory and 8 hours for laboratory practice are sufficient to develop good skills with the approach. However, more time should be spent for developing clinical skills since the student can encounter many different situations and difficulties ${ }^{26}$ when applying the ART approach, such as different occlusal access ${ }^{31}$, consistency and depth of the dentin lesion ${ }^{5}$.

The ART approach was developed in Tanzania in the mid-1980's ${ }^{16,18}$. However, it was only in 1994 that the WHO recognized it as a revolutionary technique for caries lesion treatment ${ }^{37}$. The Brazilian dental schools delayed some years before including ART on their undergraduate curricula but even so the majority of dental schools have been teaching the ART approach for between 4 to 10 years. There remains a diversity in terms of hours spent, kind of teaching (theory and practice) and disciplines involved. Ideally, if the school really accepted the ART approach, all the disciplines cited (Pediatric Dentistry, Public Health Dentistry and Operative Dentistry) should teach this approach. This fact points out that it is necessary to address a training of professors covering the whole country.

In 1993, 1996 and 2003, the DMFT (at 12 years of age) reported for Brazil was 4.90, 3.06 and 2.78, respectively, according to the Ministry of Health of Brazil ${ }^{8}$. This shows a clear decrease of the DMFT throughout the years that is associated with many factors, including the use of fluoride in the drinking water, the use of fluoride toothpastes, and the implementation of new government programs focused on oral health. The majority of the professors did not note differences in the DMFT after the introduction of the ART approach because it is part of health 
programs. Considering the FHP and "Brazil Smiling Program", it would be very important to motivate professors from target groups, as those from Pediatric Dentistry, Operative Dentistry and Public Health Dentistry, and practitioners already working in these programs to participate in a training covering the whole country using tools such as e-learning with classes addressed by expert professors and books or printed material regarding the ART, aiming to get the best of the ART approach ${ }^{17,18,30}$. In these classes the survival rate of ART restorations in different clinical trials should be stressed ${ }^{2,19,39}$.

Based on the current knowledge on the state of the ART approach and on the experiences of dental schools that have introduced ART in the curriculum, an educational model presenting the ART features as part of restorative and preventive caries care modules should be established to facilitate and standardize the introduction and adoption of the ART approach in the undergraduate education in Brazil.

\section{CONCLUSIONS}

There is a diversity in the ART teaching in Brazil in terms of hours spent, kind of teaching (theory and practice), and disciplines involved. It is necessary to address a training of professors covering the whole country. An educational model presenting the ART features as part of restorative caries care modules should be established to facilitate and standardize the introduction and adoption of the ART approach in the undergraduate education in Brazil.

\section{ACKNOWLEDGEMENTS}

The authors wish to thank those professors who returned the questionnaires for their precious time spent on participating in this study.

\section{REFERENCES}

1- Arbab-Chirani R, Vulcain JM. Undergraduate teaching and clinical use of rotary nickel-titanium endodontic instruments: a survey of French dental schools. Int Endod J. 2004;37:320-4.
2- Barata TJ, Bresciane E, Mattos MC, Lauris JR, Ericson D, Navarro MF. Comparasion of two minimally invasive methods on the longevity of glass ionomer cement restorations: short-term results of a pilot study. J Appl Oral Sci. 2008;16:155-60.

3- Bastos JR, Aquilante AG, Almeida BS, Lauris JR, Bijella VT. Professional profile analysis of dentists graduated at Bauru Dental School - University of São Paulo between 1996 and 2000. J Appl Oral Sci. 2003;11:283-9.

4- Beiruti N, Frencken JE, Mulder J. Comparison between two glassionomer sealants placed using finger pressure (ART approach) and a ball burnisher. Am J Dent. 2006;19:159-62.

5- Bönecker M, Grossman E, Cleaton-Jones PE, Parak R. Clinical, histological and microbiological study of hand-excavated carious dentine in extracted permanent teeth. SADJ. 2003;58:273-8.

6- Brasil. Ministério da Saúde. Avaliação normativa do Programa Saúde da Família: monitoramento da implantação e funcionamento das equipes de saúde da família: 2001-2002. Brasília: Ministério da Saúde; 2004.

7- Brasil. Ministério da Saúde. Brasil Sorridente. Brasília: Ministério da Saúde; 2006 [online]. [cited at 2010 March 15] Available from: <http://portal.saude.gov.br/saude/visualizar_texto. cfm?idtxt $=19578>$.

8- Brasil. Ministério da Saúde. Secretaria de Atenção à Saúde. Departamento de Atenção Básica. Coordenação Nacional de Saúde Bucal. Projeto SB Brasil 2003: condições de saúde bucal da população brasileira. Brasília: Ministério da Saúde; 2004.

9- Bresciani E. Clinical trials with Atraumatic Restorative Treatment (ART) in deciduous and permanent teeth. J Appl Oral Sci. 2006;14 (sp. issue):14-9.

10- Bresciani E, Carvalho WL, Pereira LC, Barata TJ, GarcíaGodoy F, Navarro MF. Six-month evaluation of ART one-surface restorations in a community with high caries experience in Brazil. J Appl Oral Sci. 2005;13:180-6.

11- Cefaly DF, Barata TJ, Tapety CM, Bresciani E, Navarro MF. Clinical evaluation of multisurface ART restorations. J Appl Oral Sci. 2005;13:15-9.

12- Cordeiro, ML, Tokunaga EM, Brusco EH, Imparato JC. Materiais restauradores ionoméricos para a técnica do tratamento restaurador atraumático. J Bras Clin Odontol Integr. 2001;5:50711.

13- Eid NL, Aquilino RN, Pereira CB, Bóscolo FN, Haiter Neto F. Avaliação do conhecimento e utilização da certificação digital em clínicas de radiologia odontológica. Revista da ABRO. 2007;8:5-10. 14- Ercan E, Dülgergil CT, Soyman M, Dalli M, Yildirim I. A fieldtrial of two restorative materials used with Atraumatic Restorative Treatment in rural Turkey: 24-month results. J Appl Oral Sci. 2009; 17:307-14.

15- Escola Nacional de Saúde Pública. Departamento de Administração e Planejamento em Saúde. Ministério da Saúde. Fundação Oswaldo Cruz. Saúde da Família: avaliação da implementação em dez grandes centros urbanos: síntese dos principais resultados. Rio de Janeiro: Ministério da Saúde; 2005. 16- Frencken JE, Holmgren CJ. ART: a minimal intervention approach to manage dental caries. Dent Update. 2004;31:295301.

17- Frencken JE, Holmgren CJ. The ART approach step-by-step. In: Atraumatic Restorative Treatment approach to control dental caries: Nijmegen: STI Books; 1999.

18- Frencken JE, van Amerongen $\mathrm{E}$, Phantumvanit $\mathrm{P}$, Songpaisan $\mathrm{Y}$ Pilot T. Manual for the Atraumatic Restorative Treatment Approach to control dental caries: Groningen: WHO Collaborating Centre for Oral Health Services Research; 1997.

19- Frencken JE, Taifour D, Van't Hof MA. Survival of ART and amalgam restorations in permanent teeth of children after 6.3 years. J Dent Res. 2006;85:622-6.

20- Frencken JE, Van 't Hof MA, van Amerongen WE, Holmgren CJ. Effectiveness of single-surface ART restorations in the permanent dentition: a meta-analysis. J Dent Res. 2004;83:120-3. 
21- Gomes KO, Cotta RM, Euclydes MP, Targueta CL, Priore SE, Franceschini SC. Evaluation of the impact of the Family Health Program in the epidemiology profile of the rural population of Airões, city of Paula Cândido (MG), 1992-2003. Cienc Saúde Coletiva. 2009;14(Suppl 1):1473-82.

22- Instituto Brasileiro de Geografia e Estatística. Pesquisa Nacional por Amostra de Domicílio. Rio de Janeiro: IBGE; 1998. 23- Kikwilu EN, Frencken JE, Mulder J. Barriers to the adoption of the ART approach as perceived by dental practitioners in governmental dental clinics, in Tanzania. J Appl Oral Sci. 2009;17:408-13.

24- Kikwilu EN, Frencken JE, Mulder J, Masalu JR. Dental practitioners' attitudes, subjective norms and intentions to practice Atraumatic Restorative Treatment (ART) in Tanzania. J Appl Oral Sci. 2009;17:97-102.

25- Lim MV, Afsharzand Z, Rashedi B, Petropoulos VC. Predoctoral implant education in U.S. dental schools. J Prosthodont. 2005; 14:46-56.

26- Mickenautsch S, Frencken JE, Van't Hof M. Factors inhibiting the implementation of the Atraumatic Restorative Treatment approach in public oral health services in Gauteng Province, South Africa. J Appl Oral Sci. 2007;15:1-8.

27- Mickenautsch S, Grossman E. Atraumatic Restorative Treatment (ART): factors affecting success. J Appl Oral Sci. 2006;14(Suppl):34-6.

28- Monico M, Tostes MA. A simplified restorative treatment for child care (ART). J Bras Odontopediatr Odontol Bebê. 1998;1:9-16. 29- Myers R, Yoon AJ. Faculty credentialing: a survey of forty-six U.S. dental schools. J Dent Educ. 2006;70:636-43.

30- Navarro MF, Pascotto RC. Cimentos de ionômero de vidro aplicações clínicas em Odontologia. São Paulo: Artes Médicas; 1998.
31- Navarro MF, Rigolon CJ, Barata TJ, Bresciane E, Fagundes TC, Peters MC. Influence of occlusal access on demineralized dentin removal in the Atraumatic Restorative Treatment (ART) approach. Am J Dent. 2008;21:251-4.

32- Pilot T. Introduction - ART from a global perspective. Community Dent Oral Epidemiol. 1999;27:421-2.

33- Rabello T. Research proposal: evaluation of the ART approach in elderly patients. J Appl Oral Sci. 2006;14(Suppl):30-3.

34- Santos JC, Rumel D. Emergência médica na prática odontológica no Estado de Santa Catarina: ocorrência, equipamentos e drogas, conhecimento e treinamento dos cirurgiões-dentistas. Ciênc Saúde Coletiva. 2006;11:183-90.

35- Topaloglu-Ak A, Eden E, Frencken JE. Perceived dental anxiety among schoolchildren treated through three caries removal approaches. J Appl Oral Sci. 2007;15:235-40.

36- Vieira AL, Zanella NL, Bresciani E, Barata TJ, Silva SM, Machado $M A A$, et al. Evaluation of glass ionomer sealants placed according to the ART approach in a community with high caries experience: 1-year follow-up. J Appl Oral Sci. 2006;14:270-5.

37- World Health Organization. Revolutionary new procedure for treating dental caries. Geneva: WHO; 1994; Available from: http://www. who.int/archieves/inf-pr-1994/pr94-28.htm 1994.

38- Zanata RL. Research proposal: evaluation of ART in adult patients. J Appl Oral Sci. 2006;14(Suppl):25-9.

39- Zanata RL, Fagundes TC, Freitas MC, Lauris JR, Navarro MF. Ten-year survival of ART restoration in permanent posterior teeth. Clin Oral Investig. 2010; in press.

40- Zanata RL, Navarro MF. International symposium of Atraumatic Restorative Treatment: proceedings of the symposium held on 4-5 June 2004 at Bauru Dental School, Bauru, São Paulo, Brazil. ] Appl Oral Sci. 2006;14(Suppl): 1 . 